\title{
INFLUNCE OF TYPE OF BEEHIVES ON FORAGING OF BEE ACTIVITY,AMOUNTS OF STORED POLLEN AND HONEY YIELD.
}

Fathy, H.M.; ; Lila. A. EL- Batran; ${ }^{*}$ H. A.M. Mansour; ${ }^{* *}$ R.A. Taha **

Econ. Entomol. Dept., Fac. Agric., Mansoura Univ.

Res. bees Dept.., Sakha Agric. Res. Station, Plant Prot. Res. Inst., Agric. Res. Center.

\begin{abstract}
The present study was conducted at the experimental farm of Sakha Agricultural Research Station Mahlet Musa, KafrelSheikh Governorate during the period from the beginning of September 2012 to the end of August 2013.The study handelt the effect of type of beehives on foraging activity, stored pollen and honey yield. The mean numbers of incoming workers/colony/minute stored pollen area/ colony with square inchs and honey yield/colony with $\mathrm{kg}$. The results which obtained from colonies housed in foam beehives were significantly higher than those from langstroth colonies ones during all experimental periods. The highest mean number of incoming workers/colony/minute and stored pollen area were recorded in colonies of Foam beehives during May and June. The amount of honey yield per colony was arranged in descending orders as follow: clover honey $>$ citrus honey $>$ cotton honey.
\end{abstract}

Keywords: Beehives, Foam, honey yield, Langstroth, stored pollen

\section{INTRODUCTION}

Activity and behavior of the honeybee Apis mellifera L. depend upon many factors operating simultaneously and react to some environmental conditions in a similar manner wherever they occur. Foraging for nectar and pollen is a continuous process throughout the year in tropical and sub-tropical areas, where bee flora is available. However, the foraging activities of honeybees for pollen are greatly influenced by the weather conditions and availability of pollen (Neupane and Thapa, 2005).

Foraging for nectar and pollen was continued throughout the year. The rate of foraging activity was affected by availability of bee flora, colony strength and weather factors. Environmental conditions included weather factors and bee flora have been affected pollen gathering activity. The maximum area of stored pollen was occurred during March in India (Rahman and Rahman, 1993; Sattigi and Lingappa, 1993), during May in Egypt (Shawer, 1987; Shawer et al., 2003; Taha, 2005), during May in Yemen (Khanbash and Bin Ghodel, 1994; Al-Humyarie et al., 1999), and during September in Island of Hawaii (Arita and Fujii 1992).

The present investigation aimed to study the variation between Foam colonies and Langstroth colonies in foraging activity, amount of stored pollen and honey yield under the environmental conditions of experimeital farm, Kafrelsheikh Governorate. 


\section{MATERIALS AND METHODS}

The present study was conducted at the experimental farm of Sakha Agricultural Research Station, Mahlet Musa Kafrelsheikh Governorate during the period from the beginning of September 2012 to the end of August 2013. Twelve honeybee nucleus colonies (each five combs) of hybrid Carniola honeybee were equalized to be in the same strength (brood, bees and stored feed) headed by young sisters open mated hybrid queens. The colonies divided into two groups of six colonies. First one was housed in langstroth beehives and the second was housed in foam ones.

Foraging activity of honeybee workers was estimated by counting the numbers of incoming workers into the colony within one minute. The numbers of incoming workers carrying pollen to the hive were recorded in the same period. The counts were carried out periodically twice weekly at 09.00 to $10.00 \mathrm{~h}$ during June to September and during 12.00 to $13.00 \mathrm{~h}$ during October to May (Shawer et al., 1987). Stored pollen area was measured at twelve days intervals using an empty standard frame divided into square inches (Al-Tikrity et al., 1971).The experimental colonies were transfred to Motobes, Kafrelsheikh governorate to obtained Citrus honey and clover honey yield were calculated from the difference between weight of honeycombs before and after extraction of honey. Cotton honey yield was determined by measuring capped and uncapped honey areas and transformed into weight using the following formula:

Honey yield in $\mathrm{kg}=$

$$
\text { Area of honey (sq. inches) } \times 10.64 \mathrm{~g}
$$

Where 10.64 = amount $(\mathrm{g})$ of honey in one square inch, based on averages calculated from unsealed and sealed honey from combs of different thickness (Shawer et al., 1986).

Data were statistically analyzed by ANOVA. Pearson correlation between the measured activities was determined using SAS Institute (2003).

\section{RESULTS AND DISCUSSION}

The foraging activity was significantly $(p<0.01)$ affected by type of beehives. The numbers of incoming workers/colony/minute from colonies in foam beehives were surpassed those from langstroth ones during all experimental months. The percentages of increment per colony were ranged from 6.03 to $29.70 \%$ with average of $11.53 \%$. The highest increment $(29.70$ $\%$ ) was recorded in November, followed by $17.55 \%$ in October, while the lowest one was observed in May. In this respect, Taha (2007) found that colonies located in banana farm were exceeded those in the apiary of the Faculty of Agriculture, Kafr El-Sheikh University by $44.68 \%$ in foraging activity. The mean numbers of incoming workers/colony/minute (95.81 workers/ colony/minute) in colonies of foam beehives were significantly $(p<0.01)$ higher than those ( 86.93 workers/colony/minute) of langstroth beehives. In 
this regard, Helal et al. (2003) concluded that foraging activity of moved colonies was significantly higher than those of non-moved ones. Besides,Taha (2007) recorded that numbers of incoming workers/ colony/ minute in colonies located in banana farm exceed those in the apiary of the Faculty of Agriculture, Kafr El-Sheikh University by $44.68 \%$.

Data illustrated graphically in Fig. (1) showed that, the mean numbers of forager workers were varied significantly $(p<0.01)$ during the different months. The highest mean numbers of incoming workers/colony/minute were observed during May and June, which formed the highest peak, followed by August that formed the second peak, while the lowest numbers of incoming workers/colony/minute were found in November in both types of the beehives. The high rate of foraging activity during May and June may be attributed to the abundance of natural feed sources during clover season follow that affect the rate of egg laying activity of the honeybee queen and subsequently the population size of bee workers. These results are in agreement with those obtained by Shawer et al. (1987) who reported that flight activity and nectar gathering activity changed during the different months according to the abundance of nectar sources and weather factors. Similarly, Serag El-Dein (1991) mentioned that, flight activity of workers from April to August exceeded those from September to March. Two peaks of flight activity were observed in May (52.13 and 52.27 bees/colony/minute) and the second in July (44.64 and 44.73 bees/colony/ minute) for the first and the second seasons, respectively. In addition, Helal et al. (2003) recorded that the highest numbers of forager bees during May (clover season) and July (cotton season).

Data presented in Table (1) revealed that the numbers of pollen foragers were significantly $(p<0.01)$ affected by the type of beehives The numbers of incoming worker carrying pollen/colony/minute from colonies in foam beehives were significantly surpassed those from langstroth ones during all experimental months apart from September and March. The percentages of increment per colony were ranged from 5.17 to $57.77 \%$ with average of $21.00 \%$. The highest increment was recorded in November, followed by $47.05 \%$ in January, while the lowest one was observed in March. In this regards, Taha (2007) found that colonies located in banana farm were more active in foraging for pollen than those in the apiary of the Faculty of Agriculture, Kafr El-Sheikh University by. $61.87 \%$. 


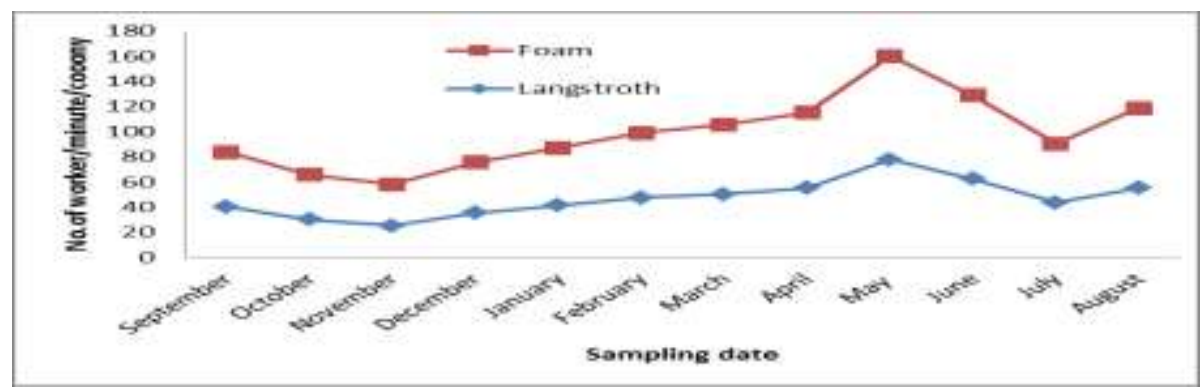

Fig. (1): Effect of beehives type (foam\& langstroth hive) on mean numbers of incoming workers/colony/ minute during season of 2012/2013.

Table (1): Effect of beehives type on mean number of incoming worker carrying pollen/colony/minute during season of 2012/2013.

\begin{tabular}{|c|c|c|c|}
\hline \multirow{2}{*}{ Months } & \multicolumn{2}{|c|}{ Beehive type } & \multirow{2}{*}{ Significant } \\
\hline & Lang. & Foam & \\
\hline September & 6.75 & 7.50 & N.S \\
\hline October & 4.25 & 5.75 & ** \\
\hline November & 2.25 & 3.55 & ** \\
\hline December & 4.10 & 5.22 & ** \\
\hline January & 4.25 & 6.25 & $\star \star$ \\
\hline February & 8.32 & 8.90 & * \\
\hline March & 14.50 & 15.25 & N.S \\
\hline April & 15.75 & 16.66 & * \\
\hline May & 27.00 & 29.75 & $\star \star$ \\
\hline June & 14.50 & 16.75 & ** \\
\hline July & 12.25 & 14.77 & ** \\
\hline August & 18.75 & 20.50 & ** \\
\hline Mean & 11.05 & 12.57 & ** \\
\hline
\end{tabular}

", ** and NS indicate $P<0.05, P<0.01$ and insignificant, respectively.

The mean numbers of incoming workers carrying pollen/colony/minute (11.05 pollen foragers/colony/minute) in colonies of foam beehives were significantly $(p<0.01)$ higher than those $(12.57$ pollen foragers/colony/minute) of langstroth beehives. The mean numbers of incoming workers carrying pollen/colony/minute were varied significantly $(p<0.01)$ during the different months. The highest mean numbers of incoming workers carrying pollen/colony/minute were observed during May, which formed the highest peak, followed by August that formed the second peak, while the lowest one was found in November in colonies of both beehives. These results are agree with those found by Shawer et al. (1987), Shawer et al. (2003), Taha (2005) and Ghazay (2009) who reported that pollen-gathering activity changed during the different months according to the abundance of pollen sources and weather factors.

The high rate of pollen forager during May was coincide with the season follow of clover that affect the rate of egg laying activity of the honeybee queen and subsequently the population size of bee workers. These 
results are in harmony with the findings of Serag El-Dein (1991) who found that, pollen gathering activity from April to August exceeded those from September to March. Two peaks of pollen gathering activity were observed in May (52.13 and 52.27 pollen foragers/colony/minute) and the second in July (44.64 and 44.73 pollen foragers/colony/minute) for the first and the second seasons, respectively. In addition, Shawer et al. (2003) recorded that the highest numbers of pollen forager were observed during May (clover season) and July (cotton season). On the other hand, Sattigi and Lingappa (1993) observed that, maximum pollen foraging activity occurred on March.

The stored pollen areas (sq. inches) were significantly $(p<0.01)$ affected by the type of beehives. The stored pollen areas (sq. inches) obtained from colonies in foam beehives were higher than those from langstroth ones during all experimental months. The percentages of increment per colony were ranged from 2.78 to $17.70 \%$ with average of $6.85 \%$. The highest increment was recorded in January, followed by $11.48 \%$ in October, while the lowest one was observed in September. In this regards, Taha (2007) found that colonies located in banana farm were more active in stored pollen than those in the apiary of the Faculty of Agriculture, Kafr El-Sheikh University by. $60.18 \%$.

The mean stored pollen areas (165.26 sq. inches/colony/month) by colonies in foam beehives were significantly $(p<0.01)$ higher than those (156.16 sq. inches/colony/ month) of langstroth ones. The mean areas of stored pollen were varied significantly $(p<0.01)$ during the different months (Fig. 2). The highest mean stored pollen areas (sq. inches/colony/month) were observed during May and June, which formed the highest peak, followed by August that formed the second peak, while the lowest one was found in January in colonies of both types of beehives. These results are in agreement with those found by Shawer et al. (1987); Serag El-Dein (1991) ; Shawer et al. (2003) and Taha et al. (2009) in Kafr El-Sheikh Governorate, as they detected that the highest mean areas of stored pollen were found in May (the blooming season of clover), followed by July and August (cotton season). Ismail (2001) noticed that during spring season (March, April and May) stored pollen area represented $44.20,43.50$ and $46.00 \%$ in treated colonies with camphor, thymus and rosemary, respectively. Most of the pollen grains were collected in March. The percentage of collected pollen during summer season (June, July and August) was estimated as 34.40, 30.90 and $33.40 \%$ in treated colonies with camphor, thymus and rosemary, respectively. 


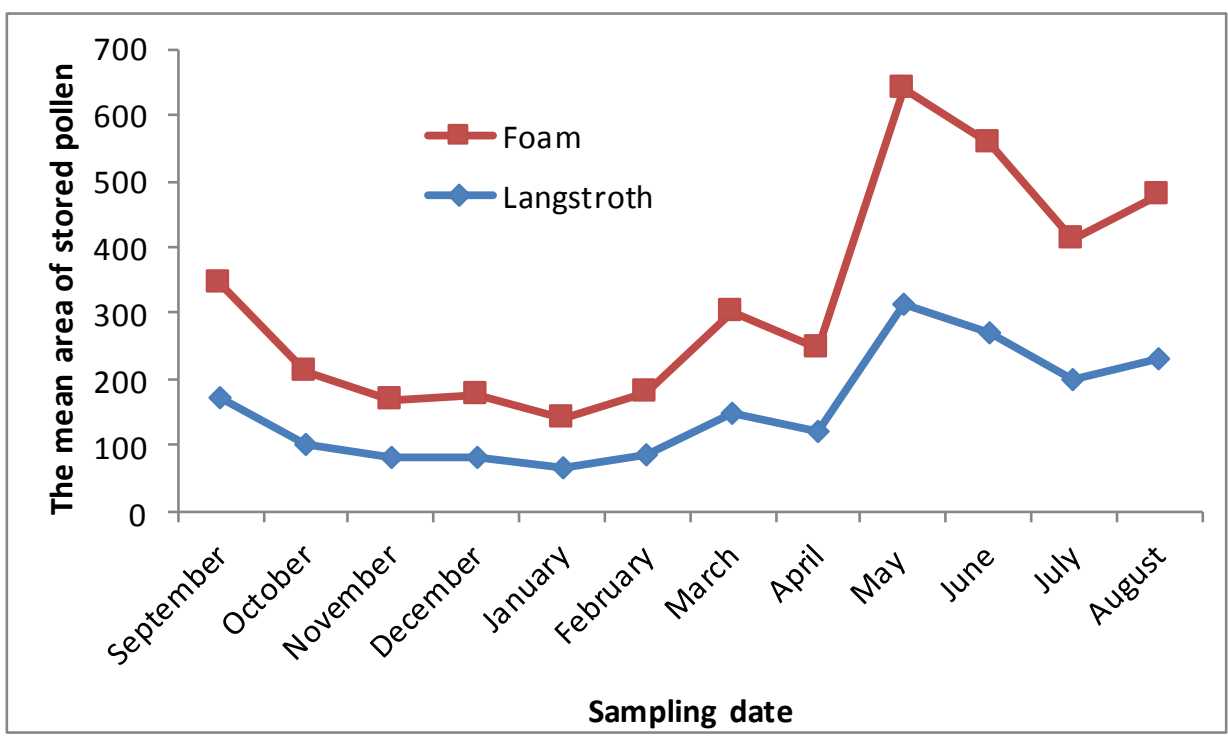

Fig. (2): Effect of hive type(foam\& langstroth hive) on mean area of stored pollen (sq. inch) during 2012/2013.

During autumn season (September, October, November) the percentage of stored pollen was $10.20,11.00$ and $10.00 \%$ in treated colonies with camphor, thymus and rosemary, respectively. During winter season (December, January and February), the percentage of pollen grains were $11.20,14.60$ and $10.60 \%$ in treated colonies with camphor, thymus and rosemary, respectively.

The differences of pollen gathering activity between colonies in foam and langstroth beehives, and among months may be due to the variability in colony strength according to the rate worker brood and subsequently the population of bee workers, which collected pollen from pollen sources. Highly significant positive relationships between stored pollen area/colony and each of mean number of incoming workers/ colony/minute $(r=0.91)$, and number of incoming workers carrying pollen/colony/ minute $(r=0.84)$ were observed (Table 2).

Table (2): correlation coefficient values for some honeybee activities during the year of 2012/2013.

\begin{tabular}{|l|c|}
\hline \multicolumn{1}{|c|}{ Comparisons } & $\mathbf{r}$ - values \\
\hline No. of incoming worker/colony/minute $\times$ stored pollen area/colony/month & $0.89^{* *}$ \\
\hline No. pollen foragers/colony/minute $\times$ stored pollen area/colony/month & $0.84^{* *}$ \\
\hline Honey yield /colony $\times$ No. of incoming workers/colony/minute & $0.89^{* *}$ \\
\hline Honey yield /colony $\times$ mean stored pollen/month/colony & $0.85^{* *}$ \\
\hline
\end{tabular}

"correlation is significant at the 0.01 level (2-tailed). 
The average amounts of honey yield per colony were significantly $(p<0.01)$ affected by the types of beehives. Data illustrated in Fig. (3) showed that, colonies in Foam beehives produced honey more than weak ones (5.50, 6.25 and $4.00 \mathrm{~kg} /$ colony vs. $4.75,5.25$ and $3.50 \mathrm{~kg} /$ colony for citrus, clover and cotton seasons, respectively). The total amount of clover honey yield/colony ( $15.75 \mathrm{~kg} /$ colony) produced by colonies in foam beehives were significantly $(p<0.01)$ higher than that $(13.50 \mathrm{~kg} /$ colony $)$ produced by colonies in langstroth hive, with increment of $16.67 \%$. The percentages of increment per colony were ranged from 14.28 to $19.04 \%$ with average of $16.37 \%$. The highest increment was recorded in clover season, followed by $15.76 \%$ in citrus season, while the lowest one was observed in cotton season. In this regard, Fathy (1998) reported that treated colonies with thymus gave an average of $4.90 \mathrm{~kg} /$ colony clover honey, while treated colonies with rosemary gave an average of $3.95 \mathrm{~kg} /$ colony. In addition, Taha (2007) found that colonies located in banana farm produced honey more than those in the apiary of the Faculty of Agriculture, Kafr El-Sheikh University by $100 \%$.

The average amount of honey yield per colony were varied significantly $(p<0.01)$ during the different seasons. The amount of honey yield per colony was arranged in descending orders as follow: clover honey $>$ citrus honey > cotton honey. These results were in harmony with those obtained by Atallah et al. (1983a); Shawer (1987), Serag El-Dien (1991), Helal et al. (2003) and Taha (2005) who recorded that, honey yield during clover blooming season was more than that of cotton. On the other hand, Abdel-Rahman (2004) reported that in Assiut region, the largest average honey yield (8.61 $\mathrm{kg} /$ colony) was obtained from cotton plants, followed by clover (3.96), then medical plants (3.08 kg/colony).

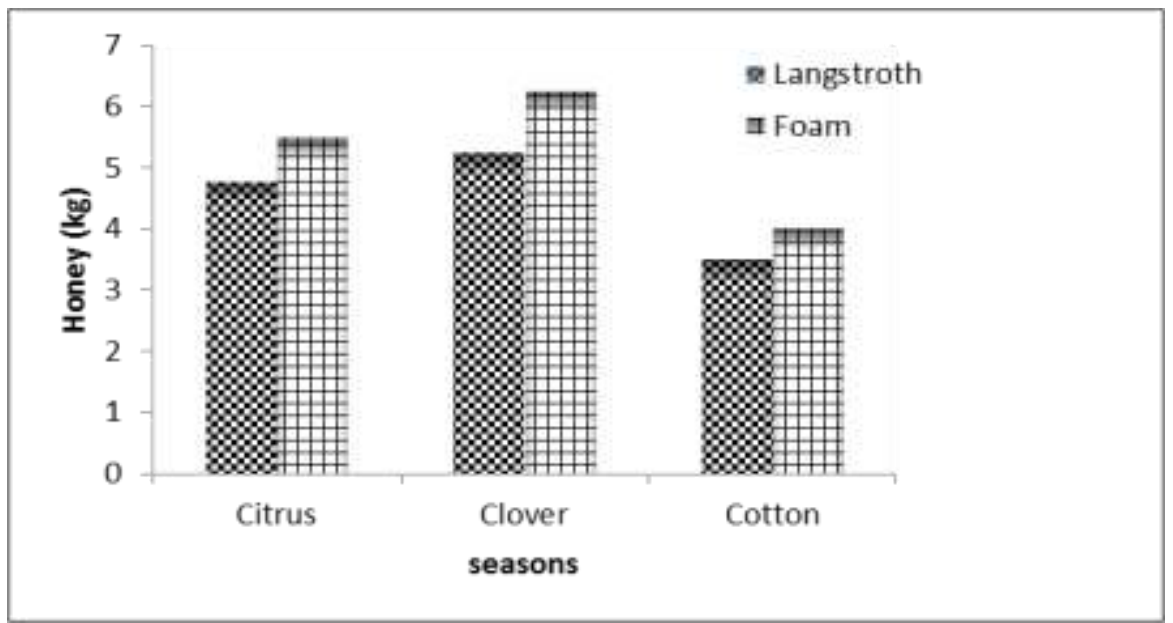

Fig. (3): Effect of beehives type (foam\& langstroth hive) on mean amount ) of honey yield ( $\mathrm{kg} /$ colony during citrus, clover and ; cotton seasons. 
Statistical analysis showed highly significant differences between langstroth and foam beehives as well as between citrus and cotton seasons. The differences between clover, citrus and cotton seasons may be due high population of bee workers, which was higher in clover season, and the area of each crop. In this regard, Shawer et al. (1986) and Marceau et al. (1990) found that honey collected by strong colonies was higher than those collected by weak ones were.

Data summarized in Table (2) show highly significant positive correlations between honey yield/colony and each of number of incoming workers/minute/colony, and mean stored pollen area/colony $(r=0.89$ and 0.85 , respectively) were found. In this respect, Ewies et al. (1980); Hussein (1981); Duff and Furgala (1986) and Shawer (1987) found that honey production of the trapped colonies was significantly less than un-trapped ones. Taha et al. (2009) found highly significant positive correlations between honey yield/colony and mean stored pollen area/12 days/colony $(r=0.63 \& 0.63)$ in 2002 and 2003, respectively.

\section{REFERANCES}

Abd El -Rahman, M. F.(2004). Comparative studies between the characters of some races and hybrids of honey bee in Assiut region, Upper Egypt. Ph. ; D. Thesis, Fac. Agric. Assuit Univ., 373 pp.

Al- Humyarie, A. A.; El - Sherif, M. E. and Naser, K. S. A. (1999). Brood rearing, food storage and worker longevity of Yemeni bee colonies and their Carniolan hybrid . J. Agric. Sci. Mansoura Univ., 24 (3): 1345 -1358.

Al-Tikrity, W. S.; Hillmann, R. C.; Benton, A. W. and Clarke, W. W. (1971). Anew instrument for brood measurement in a honeybee colony. Amer. Bee J., 111 (4) : $143-145$.

Arita, L. H. and Fujii, J. K. (1992). Quantity and seasonal variation of pollen Types collected by honey bees at two localities on island of Hawaii. Proc. of the Hawaiian Entomol. Soc., 31 (12) : 119-123.

Atallah, M.A.; Abd -El-Naby, A.A. and Moftah, E.A. (1983a). Flight activity and colony gain weight of the Egyptian and Carniolan honeybees in middle Egypt. Proc. 5th Arab Pest. Conf. Tanta Univ., 1: $74-81$.

Duff, S. R. and Furgala, B. (1986). Pollen trapping honey bee colonies in Minnesota, I: Effect on amount of pollen trapped, brood reared, winter survival, queen longevity and adult bee population. Amer. Bee J., 126 (10): 686-689.

Eweis, M. A.; Salem, M. S. and Ali, A. (1980). Brood rearing activity of the honeybee in relation to pollen gathering and some weather factors in Mostorod region. Zagazig Univ. Res. Pol., 139:1-10.

Fathy, H. M. (1998). Effects of extracts of certain medical and aromatic plants on brood rearing, stored pollen and honey production. J. Agric. Sci. Mansoura Univ., 23 (7): 3387 - 3394

Ghazy, M. G. M.(2009). Influence of some pollen substiutes on activity of honey bees. M. Sc. Thesis, Agric. Kafreisheikh Univ., 157 pp. 
Helal, R. M.; El-Dakhakhni, T. N.; Shawer, M. B. and Taha, E. A. (2003). Effect of moving the apiaries on activity of honey bee colonies. 1- Flight activity, gathering of nectar and sugar concentration contents and honey. J. Agric. Res. Tanta Univ., 29 (2): $268-282$.

Hussein, M. H. (1981). Pollen gathering activity of honey bee workers in Assiut Governorate. Proc. 4th Arab Pest. Conf. Tanta Univ. Egypt, 377- 385.

Ismail, A. A. T. (2001). Effect of some natural substances on the activity and some products of honey bee. M.Sc. Thesis, Fac. Agric., Mansoura Univ., 77 pp.

Khanbash, M. S. and Ghodel, B. (1994). Seasonal collection and storage of pollen in honey bee colonies with different sizes. J. Yemeni Agric. Res. Aden Univ. 5: $1-14$.

Marceau, J.; Boily, R.; Perron, J.M. (1990). The relationship between hive productivity and honeybee flight activity. J. Apic. Res., 29 (1), 28-34.

Neupane, K.R. and Thapa, R.B. (2005). Pollen collection and brood production by honey bees (Apis mellifera L.) under Chitwan condition of Nepal. J. Inst. Agric. Anim. Sci., 26: 143-148.

Rahman, S. and Rahman, A. (1993). Comparative pollen gathering activity of Apis cerana indica Fabr. And Apis mellifera L., Under Johrot conditions of Assam (India) Indian Bee. J. 55 (3-4) :42 - 46.

SAS INSTITUTE (1986). SAS/STAT Guide for personal Computers Version (6 Cary, Nc, SAS institute).

Sattigi, H. N. and Lingappa, S. (1993). Foraging activities of Indian honeybee Apis Cerana Fabr. Under Dharwad Conditions Karnataka J. Agric. Sc., 6 (4) : 352 -354 .

Serag El-Dein, F. S. A. (1991). Nectar and pollen gathering activity of the honeybees. M. Sc. Thesis, Fac. Agric. Tanta, Univ., 129 pp.

Shawer, M. B; Shenishen, Z. and El - Dakhakhni, N. M. (1986). Effect of colony strength on flight activity and productivity of honeybee colonies. Bull. Soc. Entomol. Egypt, $66: 65-73$.

Shawer, M. B. (1987). Major pollen sources in Kafr El - Sheikh, Egypt, and the role of pollen on brood area and honey yield .J. apic. Res., 26 (1): 43-46.

Shawer, M. B.; El-Dakhakhni, N. M.; Abd El-Rahman, I. and El-Mezayyen, G. A. (1987). Effect of some ecological factors on honeybee gathering activity and colony weight. J. Agric. Res. Tanta Univ. 13 (2) : $409-424$.

Shawer, M. B.; El-Dakhakhni, N. M.; Helal, R. M. and Taha, E. A. (2003). Effect of moving the apiaries on activity of honeybee colonies. 1- Gathering and storing pollen, brood rearing and wax secretion. J. Agric. Res. Tanta.Univ., 29 (2) : $250-267$.

Taha, E. A. (2005). Studies on honey bee (Apis mellifera L.) . Ph.D. Thesis, Tanta Univ., $151 \mathrm{pp}$.

Taha, E. A. (2007). Importance of Banana musa sp. (musaceae) for honeybee Apis mellifera L. (Hmenoptera: Apidae) in Egypt. Proc. 2nd Int. Conf. Ent. Soc. I., 125-133.

Taha, E. A. (2009). Importance of Banana Musa Sp. (Musaceeae) for Honeybee Apis mellifera L. (Hymenoptera : Apidae) in Egypt. 6th Int. Arab. Apic. Conf. 17-19 Mar., pp 140, 
Fathy, H. M. et al.

تاثير نوع الخلايا على عدد النحل السارح و تخزين حبوب اللقاح وكمية العسل

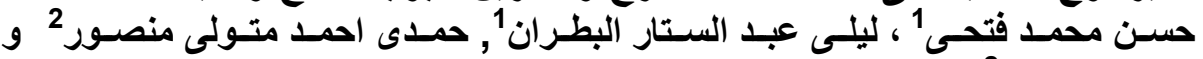

رضا عبده طه 2

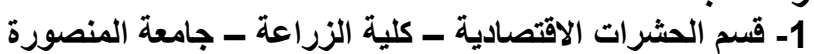

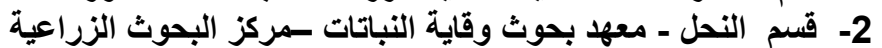

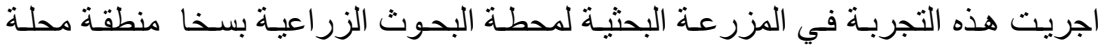

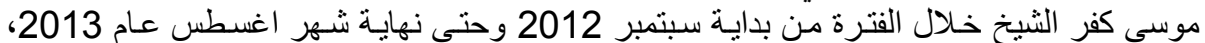

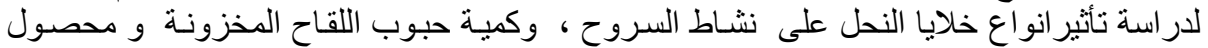

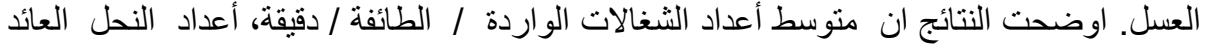

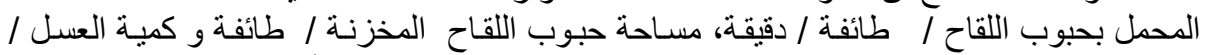

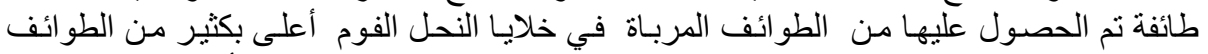

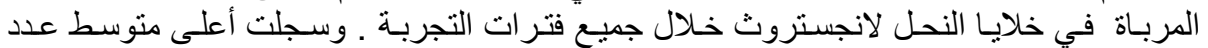

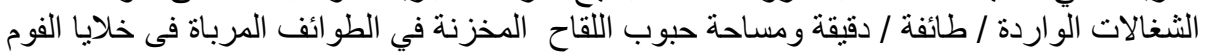

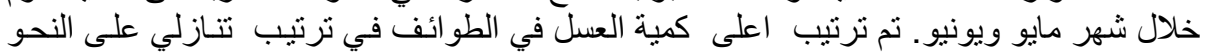
التالي: العل البرسيم ثم العسل المو الح ثم القطن العسل. 